\title{
層降伏型建物における RC 柱一組積造充填壁の相互作用モデル MODELING FOR INTERACTIONS BETWEEN R/C COLUMN AND MASONRY INFILL IN BUILDINGS WITH COLUMN-SWAY MECHANISM
}

\author{
真田靖士*，マイディアワティ** \\ Yasushi SANADA and Maidiawati
}

\begin{abstract}
This paper proposes a new analytical model for evaluating interactions between $\mathrm{R} / \mathrm{C}$ column and masonry infill. Infill was replaced by a diagonal strut, and its width was defined by the column/infill contact length. A calculation procedure was presented to determine the contact length mainly considering the compression balance and lateral displacement compatibility at the column/infill interface. The proposed model was verified comparing to the past experiment on concrete block infilled $\mathrm{R} / \mathrm{C}$ frame in which the column/infill interactions were observed in detail. Consequently, it could evaluate not only the strength of infilled frame but also ductility well.
\end{abstract}

Keywords: analytical model, nonstructural infill wall, reinforced concrete column, seismic performance evaluation, strut 解析モデル，非構造充填壁，鉄筋コンクリート柱，耐震性能評価，ストラット

\section{1. はじめに}

海外の建物で用いられる組積造による非構造充填壁が建物の構造 性能に少なからず寄与することが実証されている例えば, 1), 2).この種 の壁は地震時に面外方向への転倒や部分崩落などが懸念されるため, 地震国での使用は本来適切ではなく，将来的には RC 壁やカーテン ウォールなどの脱落がない構造の採用が望まれる．しかしながら， 既存建物はもとより, 途上国では現在も新築建物で採用されており, こうした建物の耐震性能を精度よく評価するためには, 組積造壁の 影響を適切に考慮する必要がある。

上記の背景から，海外を中心に組積造の非構造壁の解析モデルが 数多く提案されている. とくに非構造充填壁は周辺構造躯体と相互 に影響し合うが，こうした相互作用を評価することに着眼したモデ ルとして, 古典的には弾性床上の線材の曲げ変形を仮定した Smith のモデル ${ }^{3)}$, 充填壁を斜め圧縮ストラット置換しマクロ挙動を表現 した Wood のモデル ${ }^{4)}$, 有限要素法に基づく Liauw らの評価法 ${ }^{5}$ など が挙げられる．近年においてもより精緻な有限要素法解析による分 析が複数報告されているが例齐ば6)，例えばわが国の耐震診断 ${ }^{7}$ 程度の 実務での利用を想定すると, ある程度マクロなモデルによる評価が 望ましいと判断される。

一方，筆者らは非構造充填壁と $\mathrm{RC}$ 構造躯体の相互作用を実験的 に検討してきており，とくに文献 8)では充填壁と柱の負担力を分離 して評価する実験を行い，こうした相互作用を精緻に議論する実験 的な資料を保有している，そこで，本稿では既往のマクロモデルと は異なるアプローチから，わが国の耐震診断をこの種の構造に適用 する場合に必要となる充填壁の強度と, 周辺 $\mathrm{RC}$ 架構の変形性能を 合理的に評価するための新たなマクロモデルを提案する．また，筆
者らの既往の実験結果を提案するモデルにより評価し，その妥当性 について分析した結果をまとめる.

\section{R C 柱一組積造充填壁の相互作用モデル}

\section{1 柱一充填壁の接触長さに基づく充填壁のストラット置換}

本稿の研究対象は, 柱の降伏が先行する層降伏型の RC 架構に, 組積造充填壁が非構造壁として設けられた，いわゆるインフィル架 構とする.この種の架構に地震力が作用し水平変形が生じたときの 概念図を図 1(a)に示寸，柱と充填壁，梁と充填壁の境界に接触領域 と非接触領域が生じる，本研究では柱降伏が先行する架構を対象と するため，柱と充填壁の接触領域に着目する．以下では，この接触 領域長さの簡潔な算定手順を導くことで，柱と充填壁の相互作用の 効果を合理的に評価する方法を提示する.

充填壁の効果をマクロに表現するため, 図 1(b)に示すように充填 壁をその対角線に平行かつ対称な斜め圧縮ストラットに置換する. ストラットの厚さと材料特性は充填壁と同一とする．最近の実験研 究 ${ }^{9)}$ ではストラットの幅は, 端部と中央で不均一であり, 端部より も中央の幅が広いことが明らかとなっているが，本研究ではストラ ットの強度評価を重視し，最も応力度が大きくなる端部すなわち柱 と充填壁境界の接触領域長さに基づいてストラット幅を定義する. また, 同研究 9)ではストラットが対角線に対しておよそ対称に形成 されることも報告されており，本研究のモデル化方針の妥当性をお よそ裏付けている，図1(b)に同じく示寸ように，本研究では柱と充 填壁の接触領域を柱が曲げ変形，充填壁がせん断変形すると想定し た場合の接触領域として評価する。この仮定の下では，ストラット の幅方向の圧縮ひずみ度は, 同図の圧縮側柱と充填壁の境界を示し
$*$ 大阪大学大学院工学研究科 准教授・博士 (工学)
** 豊橋技術科学大学大学院工学研究科 大学院生・修士 (工学)
Assoc. Prof., Graduate School of Engineering, Osaka University, Dr. Eng.

Graduate Student, Graduate School of Engineering, Toyohashi University of Technology, M. Eng. 
た拡大図より, 接触領域における柱の曲げ変形と充填壁のせん断変 形の差分（同図の $\left.\delta_{i}(y)-\delta_{c}(y)\right)$ を当該高さで交わるストラットの 初期長さ $\left(\right.$ 同図の $\left.l_{s}(y)\right)$ で除した商の分布と相似形とみなせるため, これを平均ひずみ度に置換して表現する。ここで，ストラットの幅 方向の応力度分布がひずみ度分布に比例すると仮定すると, ストラ ットの平均強度は式 1,2 により評価される。

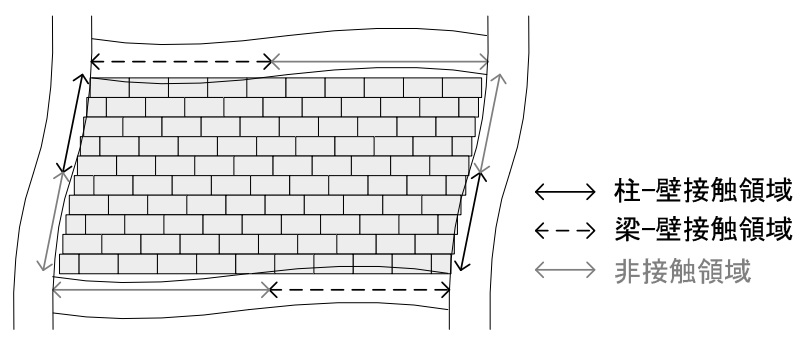

(a) 架構の水平変形時における架構と充填壁の接触
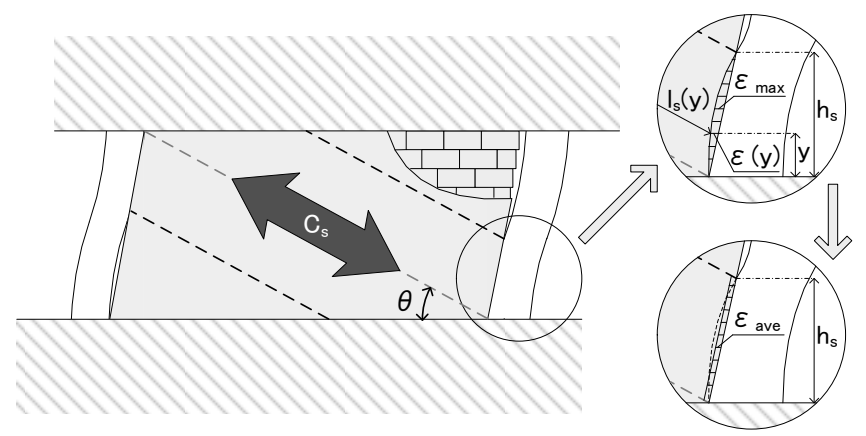

ここで, $\varepsilon(\mathrm{y})=\left(\delta_{i}(\mathrm{y})-\delta_{c}(\mathrm{y})\right) \cos \theta / \mathrm{s}_{s}(\mathrm{y})$,

$\delta_{i}(\mathrm{y}), \delta_{\mathrm{c}}(\mathrm{y})$ : 高さy $\mathrm{y}$ 充填壁と柱の水平変形,

$\mathrm{I}_{\mathrm{s}}(\mathrm{y}):$ 高さyで交わるストラットの初期長さ

(b) 充填壁の圧縮ストラット置換

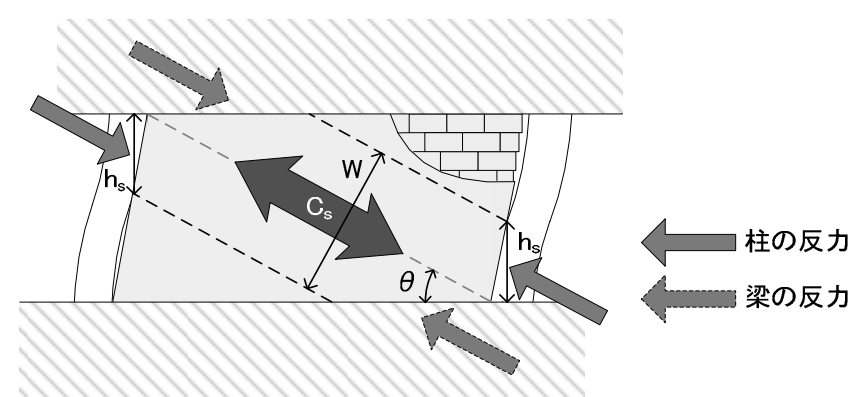

(c) 圧縮ストラットに対する架構の反力

図 1 モデル化の概念図

$$
\begin{aligned}
& \overline{f_{m}}=\alpha f_{m} \\
& \alpha=\frac{\varepsilon_{\text {ave }}}{\varepsilon_{\max }}=\frac{\int_{0}^{h_{s}} \varepsilon(y) d y / h_{s}}{\varepsilon_{\max }}
\end{aligned}
$$

ここで, $\overline{f_{m}}$ : 圧縮ストラットの平均強度, $\alpha$ : 圧縮ストラットの強 度低減係数, $f_{m}$ : 充填壁の材料強度, $\varepsilon(y)$ : 柱高さ $y$ における柱の曲 げ変形と充填壁のせん断変形の差分を当該柱高さで交わるストラッ トの長さで除した商, $\varepsilon_{\text {ave }}, \varepsilon_{\text {max }}$ : 柱と充填壁の接触領域における $\varepsilon(y)$ の平均值と最大值, $h_{s}$ : 柱と充填壁の接触領域高さである.
圧縮ストラットの端部では柱からの反力が図 1(c)に示すように作 用寸る. 同図の通り，ストラットは充填壁の対角線に対し平行かつ 対称との仮定から，柱からの反カがストラット（ストラットのみを 切り出した自由体）に不釣合モーメントを発生するが，これを打ち 消す梁からの反力を仮想するとモーメントの釣り合いが満足される. 従って, ストラットの幅は式 3 により定義され, その圧縮強度は式 4 により与えられる. 式 4 を柱と充填壁の接触領域における単位長 さあたりに作用する水平力と鉛直力として表現すると式 $4 \mathrm{a}, 4 \mathrm{~b}$ の通 りである.なお，梁と充填壁の接触領域における単位長さあたりに 作用する水平力と鉛直力は式 $4 \mathrm{~b}, 4 \mathrm{c}$ により評価される.

$$
\begin{aligned}
& W=2 h_{s} \cos \theta \\
& C_{s}=W t \overline{f_{m}} \\
& c_{h}=t \overline{f_{m}} \cos ^{2} \theta \\
& c_{v}={ }_{b} c_{h}=t \overline{f_{m}} \sin \theta \cos \theta \\
& { }_{b} c_{v}=t \overline{f_{m}} \sin ^{2} \theta
\end{aligned}
$$

ここで, $W$ : 圧縮ストラットの幅, $\theta$ : 圧縮ストラット（充填壁の 対角線）の水平面に対する角度, $C_{s}$ : 圧縮ストラットの強度, $t$ : 圧 縮ストラットの厚さ, $c_{h}, c_{v}$ : 圧縮ストラットの強度時に柱と充填 壁の接触領域に作用する単位長さあたりの水平力と鉛直力, ${ }_{b} c_{h}$, ${ }_{b} c_{v}$ : 圧縮ストラットの強度時に梁と充填壁の接触領域に作用寸る 単位長さあたりの水平力と鋁直力である.

柱と充填壁の接触領域高さ $h_{s}$ の評価手順を図 2 に示す. $h_{s}$ は圧縮 側柱または引張側柱と充填壁の各接触領域高さの最小值を採用する 柱の曲げ変形は，柱高さに沿うモーメントの分布を柱端部の曲げ降 伏を想定して式 $5 \mathrm{a}, 5 \mathrm{~b}$ の通り求め, また, 曲率分布がモーメント分 布と相似形と仮定し積分することで式 $6 \mathrm{a}, 6 \mathrm{~b}$ により評価した。ここ で, 柱高さyの原点は圧縮側柱では柱脚, 引張側柱では柱頭である. また, $h_{s}$ は予め仮定する必要があり, 同図に示す通り, 繰り返し計 算を通して $\alpha$ ，柱の軸力 $N$ （式 8 ）とともに得られる.

$$
\begin{aligned}
& 0 \leq y \leq h_{s} \text { のとき } \\
& M_{c}(y)=\frac{1}{2} c_{h} y^{2}-Q_{c e} y+M_{u} \\
& \delta_{c}(y)=\iint \phi_{c}(y) d y^{2}=\frac{1}{E I}\left(\frac{1}{24} c_{h} y^{4}-\frac{1}{6} Q_{c e} y^{3}+\frac{1}{2} M_{u} y^{2}\right) \\
& h_{s} \leq y \leq h \text { のき } \\
& M_{c}(y)=\left(c_{h} h_{s}-Q_{c e}\right) y+M_{u}-\frac{1}{2} c_{h} h_{s}{ }^{2} \\
& \delta_{c}(y)=\iint \phi_{c}(y) d y^{2}=\frac{1}{E I}\left\{\frac{1}{6}\left(c_{h} h_{s}-Q_{c e}\right) y^{3}+\frac{1}{4}\left(2 M_{u}-c_{h} h_{s}{ }^{2}\right) y^{2}+\right. \\
& \left.\frac{1}{6} c_{h} h_{s}{ }^{3} y-\frac{1}{24} c_{h} h_{s}{ }^{4}\right\}
\end{aligned}
$$

ここで, $M_{c}(y):$ 柱高さ $y$ (原点は圧縮側柱では柱脚，引張側柱では 柱頭）のモーメント, $Q_{c e}$ : 柱と充填壁の接触領域側の柱端部のせん 断力, $M_{u}$ : 柱端部の終局モーメント, $\delta_{c}(y)$ : 柱高さ $\mathrm{y}$ の水平変形, $\phi_{c}(y)$ : 柱高さ $\mathrm{y}$ の曲率, $E I$ : 柱の曲げ剛性, $h:$ 柱（壁）高さであ る.ただし， $Q_{c e}$ は本稿では非接触領域側の柱端部 $(y=h)$ で回転 が生じないとの仮定の下, 式 7 を導き評価し, また, $M_{u}$ は式 8 の略 算式 ${ }^{7} に よ り$ 評価した。 


$$
\begin{aligned}
& Q_{c e}=\frac{1}{3} c_{h} h_{s}{ }^{3} / h^{2}-c_{h} h_{s}{ }^{2} / h+c_{h} h_{s}+2 M_{u} / h \\
& M_{u}=0.8 a_{t} \sigma_{y} D+0.5 N D\left(1-\frac{N}{b D F_{c}}\right)
\end{aligned}
$$

ここで, $a_{t}$ : 引張鉄筋の断面積, $\sigma_{y}$ : 鉄筋の降伏強度, $D:$ 柱のせ い, $N$ : 柱の軸力（梁とストラットによる変動軸力を考慮する）, $b$ : 柱の幅, $F_{c}$ : コンクリートの圧縮強度である.

一方, 充填壁の壁高さに沿うせん断変形は, 柱と充填壁の頂部変 形の適合を仮定すると式 9 の通りであり, 式 10 を満足する高さ $y$ が 接触領域高さ $h_{s}$ として評価される.

$$
\begin{aligned}
& \delta_{i}(y)=\gamma_{i} \mathrm{y}=\frac{\delta_{c}(y=h)}{h} \mathrm{y} \\
& \delta_{c}(y)=\delta_{i}(y)
\end{aligned}
$$

ここで, $\delta_{i}(y)$ : 壁高さ $\mathrm{y}$ の水平変形, $\gamma_{i}$ : 充填壁のせん断変形角で ある。

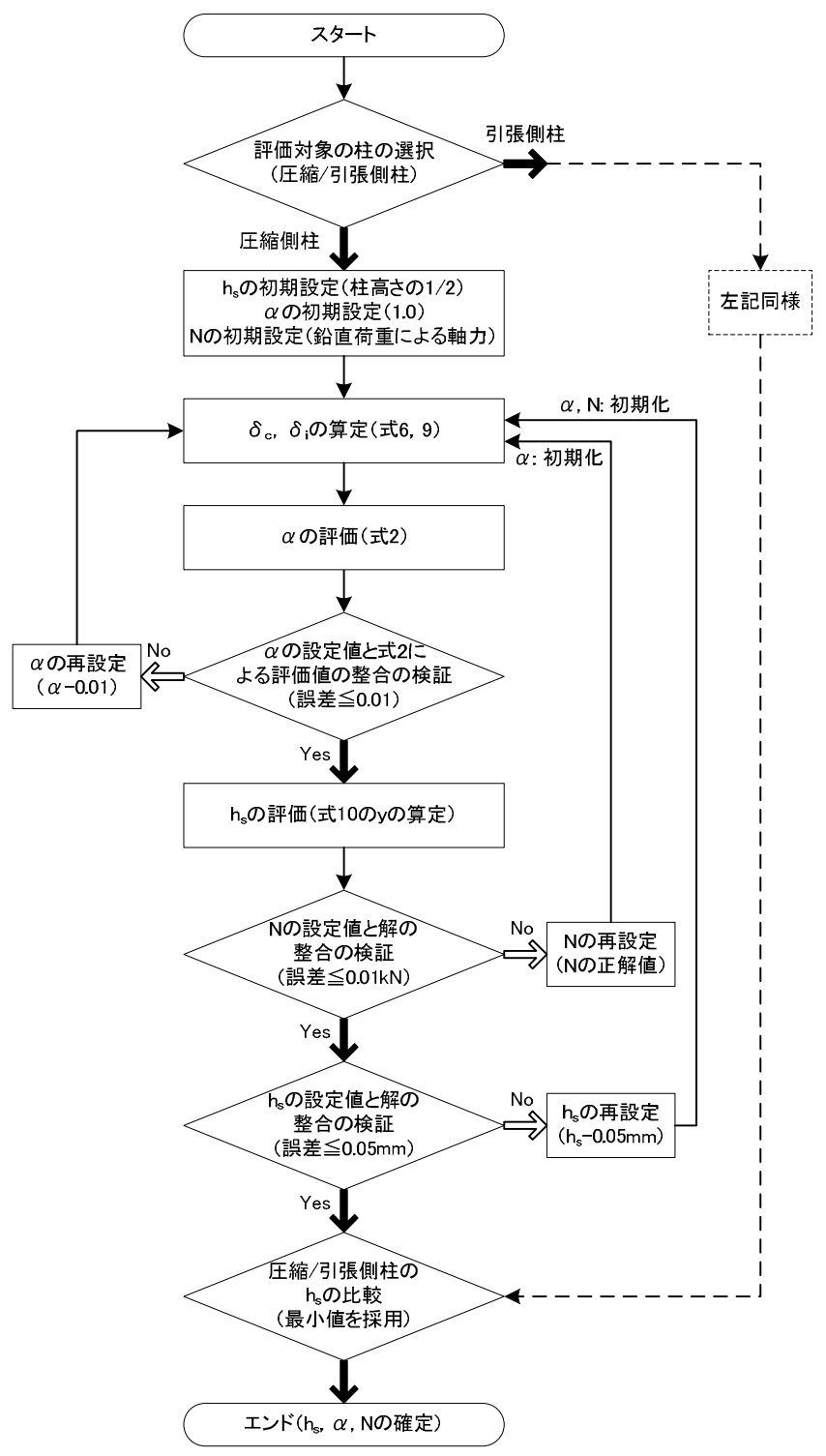

図 2 柱と充填壁の接触領域高さ $h_{s}$ の評価手順
図 2 に示すように, 上記の手順で得られた $h_{s}$ が予め仮定した值と 整合することを確認し解が得られる. その結果, 式 3 より充填壁を ストラット置換する場合の幅, 式 4 よりストラットの圧縮強度が決 定される。

\section{2 充填壁の荷重一変形関係}

以上に示した充填壁のストラット置換結果に基づいて, 充填壁の 耐震性能をわが国の耐震診断法 ${ }^{7)}$ の枠組の中で評価することを念頭 に, 水平荷重一変形関係 (せん断力一部材角関係) として評価する. 従って, バイリニアモデルに置換することを想定し, 降伏点および 限界変形の評価概念と方法を提示する.

[降伏点]

ストラットの圧縮強度が式 4 により得られるため, その水平方向 成分は式 11 により評価される. また, 降伏変形は組積ユニットの圧 縮強度時ひずみ度に基づくストラットの圧縮変形の水平方向成分と みなせるため, 式 12 により評価できる.

$$
\begin{aligned}
& Q_{i}=W t \overline{f_{m}} \cos \theta \\
& R_{i}=\left(\varepsilon_{i} l_{s} / \cos \theta\right) / h
\end{aligned}
$$

ここで, $Q_{i}, R_{i}$ : 圧縮ストラット降伏時の水平耐力と水平変形角, $\varepsilon_{i}$ : 組積ユニットの圧縮強度時ひずみ度, $l_{s}$ : 圧縮ストラットの長さ (充 填壁の対角線長さ）である.

[限界変形]

一般的な組積ユニットは脆性材料のため, 式 12 により評価される ストラットの圧縮強度時変形を限界変形とみなすことができる。し かし, 図1(b)に示したように, 本稿ではストラット幅方向の応力度 分布を等価な矩形に置換したため, 式 12 の降伏変形到達後もストラ ット幅方向内で応力の再配分が生じる可能性があり, 必ずしも急激 に耐力低下しないと考えられる。一方で, ストラットの耐力低下は ストラット自身の劣化のみならず, ストラットに反力を与える柱の 劣化によっても生じ得る. そこで, 限界変形として式 12 と, 柱のせ 几断破壞時変形の 2 通りで定義する. 後者の評価方法は以下の柱の 性能評価方法で詳述する.

\section{3 柱の荷重一変形関係}

インフィル架構の性能評価では充填壁の寄与に加えて, 充填壁と の相互作用を考慮した柱の性能評価が必要である. 充填壁と同様に わが国の耐震診断法を想定し, 柱のせん断力ー部材角関係もバイリ ニアモデルにより表現し, 第一折点および限界変形を評価する.こ こで, 第一折点とはバイリニアモデル上の降伏点を指すが, 本モデ ルでは必ずしも柱が端部で曲げ降伏する時点として定義されない. 後述するように, 第一折点は式 5 に基づいて評価するため, 柱端部 の曲げ降伏, 充填壁を模擬したストラットの上限耐力到達を条件と して, 柱と充填壁の接触領域における力の伝達を考慮して得られる 柱の作用せん断力が上限に達する時点として定義される.

[第一折点]

2.1 節より明らかなように, インフィル架構の柱のせん断力は柱 高さに沿って一様ではなく, 柱と充填壁の接触領域において局所的 に増大寸る. ここでは図 3 の左図に示すように, 柱の第一折点のせ 几断力としてその最大值が得られる接触領域端部から破壊領域を想 定した一定区間の平均值を用いることとし, 式 13 にり定義する. 


$$
\begin{aligned}
& h_{f} \leq h_{s} \text { のとき } \\
& Q_{c a}=\int_{0}^{h_{f}} Q_{c}(y) d y / h_{f}=\frac{1}{2} c_{h} h_{f}-Q_{c e} \\
& h_{f}>h_{s} \text { のとき } \\
& Q_{c a}=\int_{0}^{h_{f}} Q_{c}(y) d y / h_{f}=-\frac{1}{2} c_{h} h_{s}^{2} / h_{f}+c_{h} h_{s}-Q_{c e}
\end{aligned}
$$

ここで, $h_{f}$ : 柱端部の想定破壊領域長さ, $Q_{c a}$ : 柱と充填壁の接触領 域側の柱端部から $h_{f}$ 区間の平均せん断力, $Q_{c}(y)$ : 柱高さ $y$ のせん断 力 $\left(=\frac{d}{d y} M_{c}(y)\right)$ である.

一方, 第一折点の部材角は柱と充填壁の頂部変形の適合条件 $\left(\delta_{c}(h)=\delta_{i}(h)\right)$ より式 12 により評価される.ただし, 式 5 に基づ いて評価された式 6 では柱端部（両式中 $y=0$ の高さ）の曲げ降伏を 前提とするため, その成立を検証する必要がある. 具体的には $\delta_{c}(h)=\delta_{i}(h)$ のときの柱端部の曲率 $\phi_{c}(0)$ を算定し, これが柱曲げ降 伏時の曲率 $\phi_{y}$ を上回る, もしくは一致することを検証すればよい. $\phi_{c}(0)$ は式 14 により評価される. 一方, $\phi_{y}$ の評価手順は任意である が, 現実的な軸力下で引張主筋降伏により曲げ降伏する場合は式 15 により略算できる.

$$
\begin{aligned}
& \phi_{c}(0)=\frac{M_{c}(0)}{E I} \frac{\delta_{i}(h)}{\delta_{c}(h)} \\
& \phi_{y}=\frac{\varepsilon_{y}}{d-x_{n}}
\end{aligned}
$$

ここで, $\phi_{y}$ : 柱曲げ降伏時の曲率 (引張主筋降伏時), $\varepsilon_{y}$ : 柱主 筋の降伏ひずみ度, $d$ : 柱の有効せい, $x_{n}$ : 引張主筋降伏時の圧縮 縁からの中立軸深さである.

なお, 本稿では $\phi_{c}(0) \geq \phi_{y}$ を満たす事例について以下で検証を行 う。従って, これを満たさない場合について本稿では提案モデルの 適用範囲外と位置付ける。

[限界変形]

柱の限界変形 $R_{c}$ は，上記により評価した柱の性能曲線（せん断力 一部材角関係）とせん断耐力曲線が交差する変形, すなわち柱のせ ん断破壊時の変形として定義する. 柱のせん断耐力曲線は式 16 に示 寸 Priestley らの提案式 ${ }^{10)}$ を採用する. 図 3 の右図に限界変形の評価 概念図を示す。ここで，同図に示すように，本稿では柱の塑性率を 上述の第一折点の部材角, 寸なわち柱の作用せん断力が上限に達す る変形を基準に評価することと仮定した.

$$
V_{c}=k \sqrt{F_{c}}\left(0.8 A_{g}\right)+\frac{D-c}{h} N+\frac{A_{v} f_{y h} D^{\prime}}{s} \cot 30^{\circ}
$$

ここで, $V_{c}$ : 柱のせん断耐力, $k$ : 塑性率に基づくコンクリート強度 の低減係数で, 塑性率 $\leqq 2$ のとき $k=0.29$, 塑性率 $\geqq 4$ のとき $k=0.1$, $2<$ 塑性率 $<4$ のとき $k=$ 上記の線形補間値, $A_{g}$ : 柱の断面積, $c$ : 圧縮 縁から中立軸までの長さ, $A_{v}$ :一組のせん断補強筋の断面積, $f_{y h}$ : せん断補強筋の降伏強度, $D^{\prime}$ : せん断補強筋の平面上の中心間長さ, $s$ : せん断補強筋の部材長さ方向の間隔である.

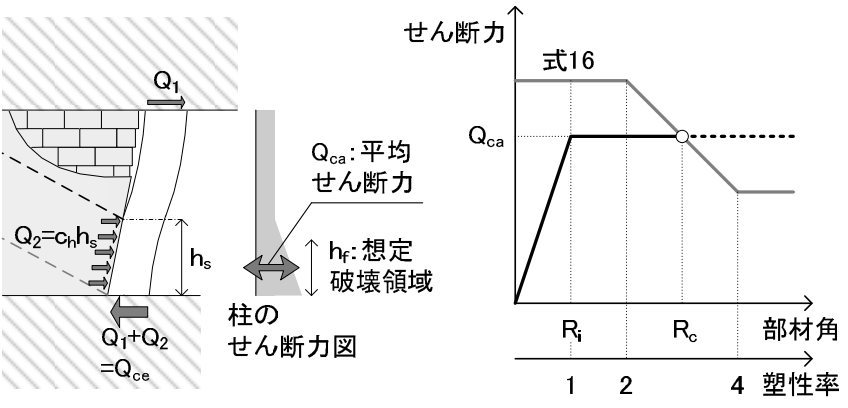

図 3 柱のせん断破壊時変形の評価概念図

\section{3. 解析モデルの検証}

本稿で提案する $\mathrm{RC}$ 柱一組積造充填壁の相互作用モデルの妥当性 を確認するためには, 一般に柱と壁が一体的に構成されるインフィ ル架構の各部位の挙動, 性能を分離して評価し得る資料が必要であ る. 筆者らの先行研究 ${ }^{8)}$ では, コンクリートブロック造充填壁を内 蔵した RC 架構を対象に, 柱の基礎下に特殊な応力計測装置を組み 込み, 柱と壁の脚部に作用寸る力を分離して評価した，そこで本稿 では，この実験結果を提案する解析モデルにより評価することで, モデルの妥当性を検証する.

\section{1 検証用構造実験の概要}

インフィル架構の柱と壁の負担力を独立して計測するため, 架構 の基礎を分割して計画した試験体を図 4 に, その構造諸元および実 験時の材料特性を表 1,2 に示す. 本試験体は 1970 年代までに建設 された既存不適格な $\mathrm{RC}$ 建物の 1 階部分を想定して設計され, 縮尺 は3/10である. また, 実験時の試験体基部における応力計測装置の 取り付け詳細を図 5 に示す. 実験では 2 台の応力計測装置が両柱基 礎下に設置された．各応力計測装置は水平力と鉛直力を検出可能な 二軸ロードセル 2 台とこれらを一体化する上下の鋼製治具より構成 される. その構造詳細や計測精度については文献8)を参照されたい.
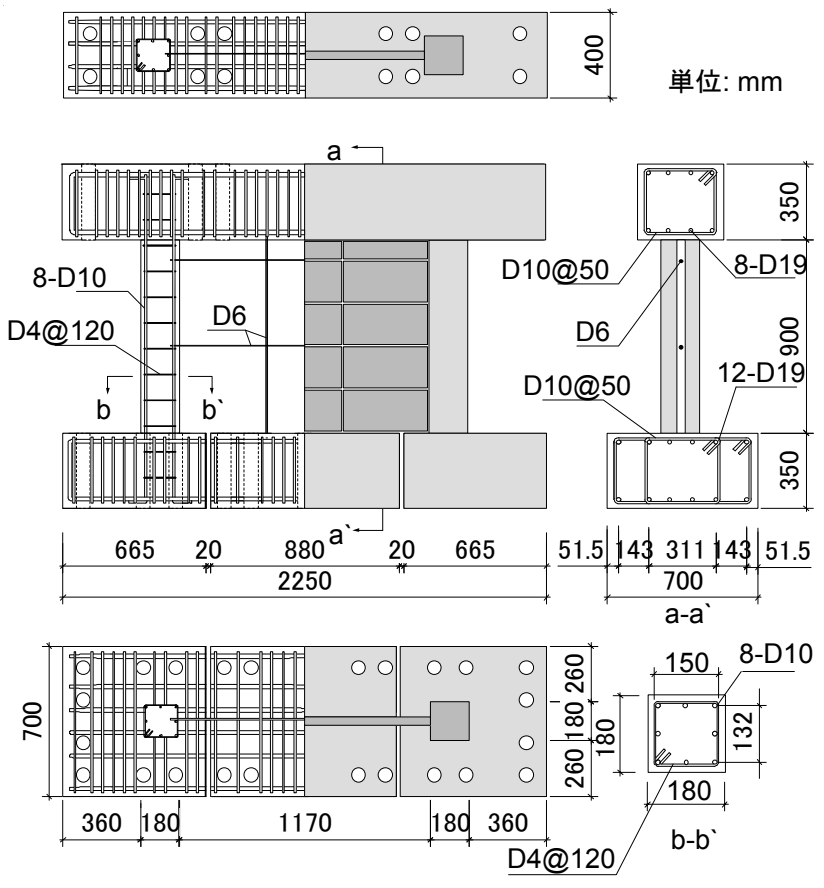

図 4 基礎分割試験体 
表 1 試験体の構造諸元

\begin{tabular}{|c|c|c|c|}
\hline \multicolumn{2}{|c|}{$\mathrm{RC}$ 柱 } & \multicolumn{2}{|c|}{ 補強コンクリートブロック壁 } \\
\hline 幅×せい & $180 \times 180$ & \multirow{2}{*}{ ブロック寸法 } & \multirow{2}{*}{$\begin{array}{l}\text { 幅 } 390 \times \\
\text { 高さ } 190\end{array}$} \\
\hline 主筋 & 8-D10 & & \\
\hline 帯筋 & 2-D4@120 & 厚さ & 70 \\
\hline \multicolumn{2}{|l|}{ 単位：mm } & 補強筋 & D6@400 \\
\hline
\end{tabular}

表 2 試験体の材料特性

\begin{tabular}{|c|c|c|c|}
\hline \multicolumn{2}{|c|}{ コンクリート } & \multicolumn{2}{|c|}{ 鉄筋 } \\
\hline ヤング係数 & $23.1 \mathrm{kN} / \mathrm{mm}^{2}$ & ヤング係数 & $184 \mathrm{kN} / \mathrm{mm}^{2}$ (D10) \\
\hline 圧縮強度 & $18.5 \mathrm{~N} / \mathrm{mm}^{2}$ & \multirow{3}{*}{ 降伏強度 } & $352 \mathrm{~N} / \mathrm{mm}^{2}$ (D10) \\
\hline \multicolumn{2}{|c|}{ コンクリートブロック } & & $339 \mathrm{~N} / \mathrm{mm}^{2}$ (D6) \\
\hline 圧縮強度※ & $14.2 \mathrm{~N} / \mathrm{mm}^{2}$ & & $383 \mathrm{~N} / \mathrm{mm}^{2}$ (D4) \\
\hline \multicolumn{2}{|c|}{ モルタル } & \multirow{3}{*}{ 引張強度 } & $492 \mathrm{~N} / \mathrm{mm}^{2}$ (D10) \\
\hline 圧縮強度 & $35.2 \mathrm{~N} / \mathrm{mm}^{2}$ & & $503 \mathrm{~N} / \mathrm{mm}^{2}$ (D6) \\
\hline \multicolumn{2}{|c|}{ ※ブロック壁の対角線方向の圧縮強度 ${ }^{8)}$} & & $537 \mathrm{~N} / \mathrm{mm}^{2}$ (D4) \\
\hline
\end{tabular}

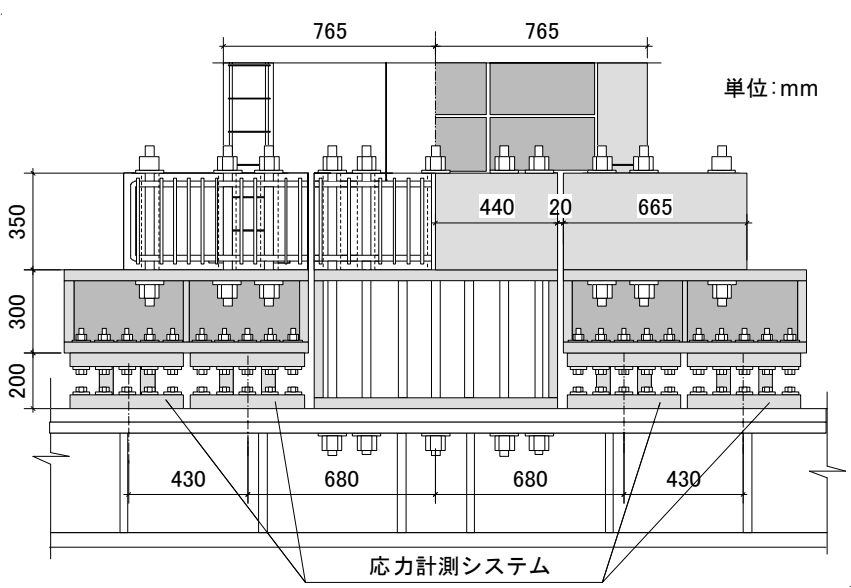

図 5 試験体基部の応力計測装置の取り付け詳細(文献 8)より再掲)

図 6 に実験装置の全体像を示す. 試験体には柱の軸力比約 0.15 に 相当する一定の鉛直荷重の下，正負交番で静的な繰り返し水平荷重 が同図のモーメント分布を維持する想定 2 階床高さに与えられた.

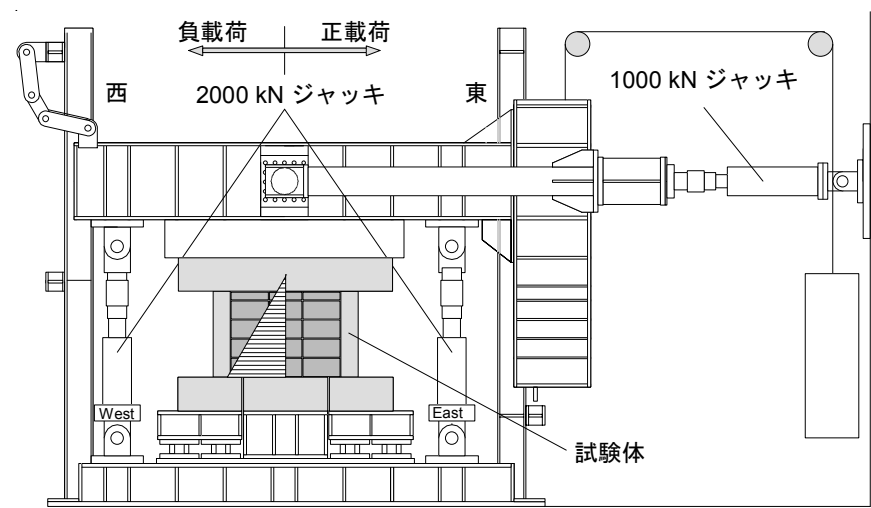

図 6 実験装置の全体像

実験より得られた試験体の荷重一変形関係と柱のせん断破壊直後 の破壊状況を図 7，8 にそれぞれ示す. 試験体は変形角（=柱・壁頂
部の水平変形 $/$ 柱・壁高さ） $\pm 1 / 200 \mathrm{rad} . の$ 載荷サイクルで柱の曲げ 降伏後に最大耐力 $230 \mathrm{kN}$ (変形角 $0.49 \% \mathrm{rad}$.) を記録した. その後, 緩やかな耐力低下を呈し, 変形角 $+1 / 100 \mathrm{rad}$. の載荷過程で圧縮側柱 脚部，引張側柱頭部のせん断ひび割れが顕著に進行するとともに， 急激な耐力低下を示した。なお，その後の正載荷では $1 / 100 \mathrm{rad}$.への 繰り返し載荷で著しく耐力低下したものの, 続く $1 / 50 \mathrm{rad}$. の載荷 時には一旦耐力が回復する傾向がみられた。これは柱のせん断破壊 により軸力が充填壁に推移し, 充填壁が摩擦抵抗を発現したためと 判断される.

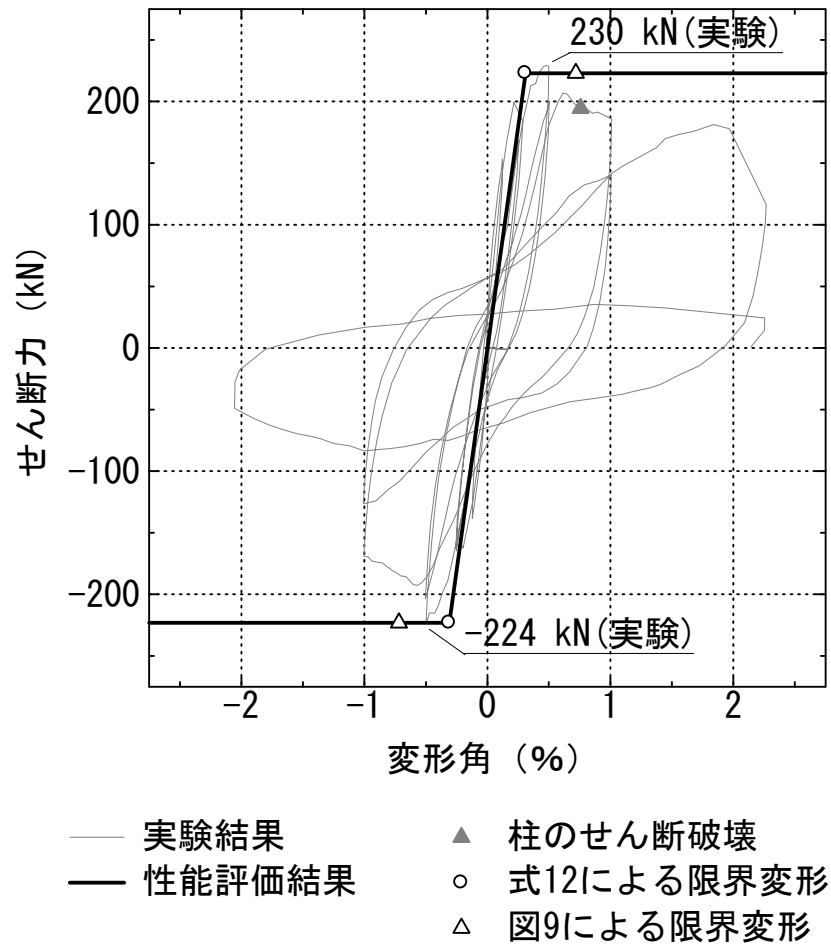

図 7 荷重一変形関係

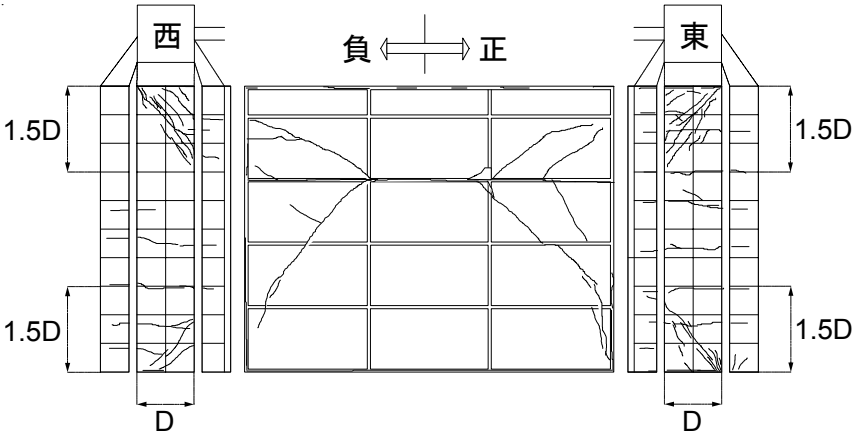

図 8 柱のせん断破壊直後（+1/100rad.への載荷後）の破壊状況

\section{2 解析モデルによる性能評価と実験結果との比較}

図 2 の手順に従って試験体の $h_{s}$ を評価した結果，並びに， $h_{s}$ に基 づいて評価さる解析モデルの主要なパラメータの評価結果を表 3 に まとめて示す.

充填壁と柱の荷重一変形関係を 2.2，2.3 節の方法に従って評価し た結果を表 3 に併せて示した。柱の限界変形は, 図 8 に示した柱の 実際の損傷領域に基づき, 式 13 の破壊領域長さ $h_{f}$ を柱端部より 
$1.5 D$ として平均せん断力を算定し, これが式 16 によるせん断耐力 と一致する変形を導いた（なお，本稿では実験結果の再現性を議論 するため， $h_{f}$ として実験值 $(=270 \mathrm{~mm})$ を用いたが，これが不明な 場合 $h_{s}(=227 \mathrm{~mm})$ を用いて評価する方法が考えられる). 図 9 にそ の評価過程を示寸. 表 3 より, 解析結果では圧縮側柱脚部, 引張側 柱頭部がそれぞれ $0.72 \% ， 0.87 \%$ でせん断破壊すると評価された。

表 3 解析モデルによる評価結果

\begin{tabular}{|c|c|c|c|}
\hline \multicolumn{2}{|c|}{ ストラット置換モデル } & \multicolumn{2}{|c|}{ 充填壁／柱の荷重－変形関係 } \\
\hline パラメータ & 評価結果 & パラメータ & 評価結果 \\
\hline$\theta$ & $38^{\circ}$ & $Q_{i}$ & $182 \mathrm{kN}$ \\
\hline$\alpha$ & 0.64 & $R_{i}$ & $0.31 \% \operatorname{rad} .{ }^{2}$ \\
\hline$\overline{f_{m}}$ & $9.1 \mathrm{~N} / \mathrm{mm}^{2}$ & $Q_{c a}$ (圧縮側) & $68 \mathrm{kN}$ \\
\hline$h_{s}$ & $231 \mathrm{~mm} * 1$ & $R_{c}$ (圧縮側) & $0.72 \% \mathrm{rad}$ \\
\hline$W$ & $367 \mathrm{~mm}$ & $\phi_{c}(0)$ (圧縮側) & $3.0 \times 10^{-5} 1 / \mathrm{mm}$ \\
\hline$C_{s}$ & $234 \mathrm{kN}$ & $\phi_{y}$ (圧縮側) & $2.3 \times 10^{-5} 1 / \mathrm{mm}^{* 3}$ \\
\hline$c_{h}$ & $402 \mathrm{~N} / \mathrm{mm}$ & $Q_{c a}$ (引張側 $)$ & $44 \mathrm{kN}$ \\
\hline$c_{v}, \quad{ }_{b} c_{h}$ & $309 \mathrm{~N} / \mathrm{mm}$ & $R_{c}$ (引張側 $)$ & $0.87 \% \mathrm{rad}$. \\
\hline${ }_{b} c_{v}$ & $238 \mathrm{~N} / \mathrm{mm}$ & $\phi_{c}(0) \quad$ (張側 $)$ & $5.0 \times 10^{-5} 1 / \mathrm{mm}$ \\
\hline & & $\phi_{y}($ 引張側 $)$ & $1.8 \times 10^{-5} 1 / \mathrm{mm}^{* 3}$ \\
\hline
\end{tabular}

※1 引張側柱の数值が最小值（圧縮側柱では $296 \mathrm{~mm}$ ) $※ 2$ 式 12 の $\varepsilon_{i}$ は実験結果がないため文献 11)より $0.15 \%$ を採用 $※ 3$ 式 15 の $x_{n}$ は断面の弾性と平面保持, コンクリートの引張力負 担無視，柱せいに沿う圧縮域の三角形応力度分布を仮定し算定
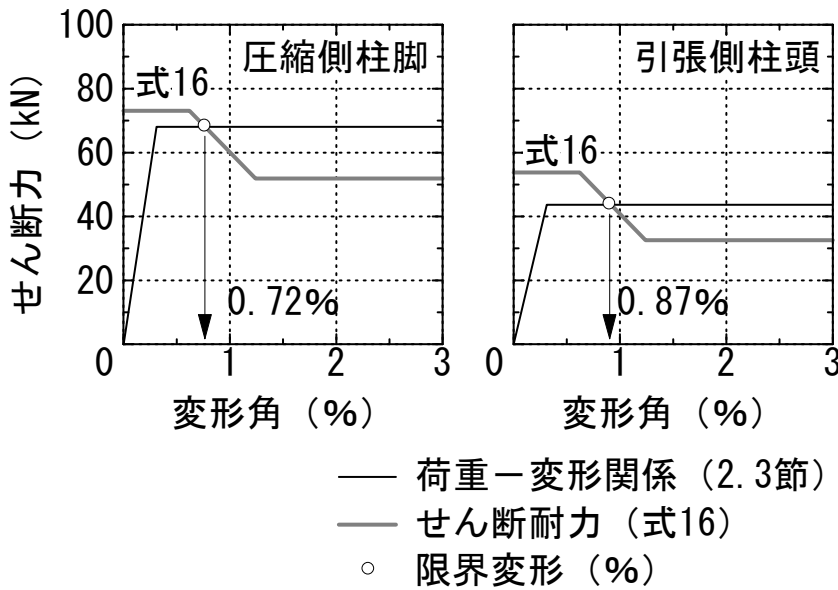

図 9 柱の限界変形の評価過程

これらの評価結果に基づいて試験体全体（インフィル架構）の性 能曲線を評価した結果を図 7 に示し, 実駼結果と比較する.ここで, 試験体全体の耐力は脚部の作用せん断力の総和として評価し（後掲 する図 11 参照), 限界変形は充填壁の強度到達時（式 12）と柱のせ ん断破壊時（圧縮側柱と引張側柱のいずれかがはじめてせん断破壊 するとき）の 2 通りを示した。 同図より，解析より評価された性能 曲線では, 最大耐力と耐力に達する変形がそれぞれ $223 \mathrm{kN}, 0.31 \% \mathrm{rad}$. であり，実駼結果（それぞれ $230 \mathrm{kN} ， 0.49 \% \mathrm{rad}$ ）を良好に捉えてい ることを確認できる。 また, 試験体の限界変形は, 柱のせん断破壊
時の変形として評価した場合が, 実験において同様に柱がせん断破 壊して耐力が急激に低下し始めた変形（繰り返し載荷時に大幅な耐 力低下を示した $1 / 100 \mathrm{rad}$.) とより整合する結果が得られた.

図 10 は本解析モデルにより評価された充填壁を置換した圧縮ス トラットが耐力に到達したときの柱の応力図である. 圧縮ストラッ トが接触する柱端部で応力伝達が生じて応力分布が急変し, とくに モーメント, せん断力, 圧縮側柱の軸力が局所的に増大しているこ とがわかる. 3.1 節の実験では試験体の基礎を分割することで, 柱 脚部と壁脚部に作用するせん断力および軸力を独立して計測した. そこで, 表 4 では試験体の最大耐力時と柱のせん断破壊時に試験体 の各基礎上で計測されたせん断力と軸力を本解析モデルによる評価 結果（図 10 の応力図に基づく）と比較する. 前者の実験值（最大耐 力時）は式 12 による限界変形 $R_{i}$ 時, 後者の実験值（せん断破壊時） は図 9 による限界変形 $R_{c}$ 時における比較を意図している.ただし, 図 4, 5 より, 試験体の柱脚下の基礎は $125 \mathrm{~mm}$ 壁脚下に張り出して いるため, 解析結果ではその影響を図 11 に示すように考慮した。 こ こで, 分割された基礎間には幅 $20 \mathrm{~mm}$ のスリットが存在するため(図 4, 5), 図 11 ではスリット中央を各基礎の境界と仮定して評価した. 表 4 より, 本解析モデルは試験体脚部の局所的な応力負担を総じて 良好に評価していることがわかる．実験值では最大耐力時からせん 断破壊時にかけて若干の数值の変動がみられるが大きくはない.こ
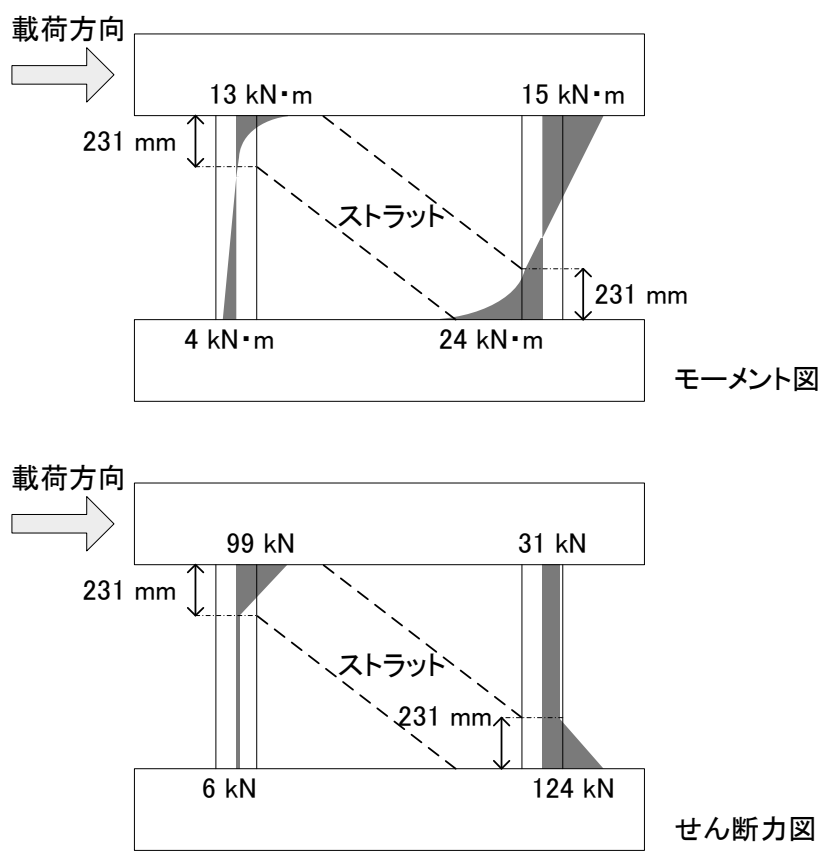

せん断力図

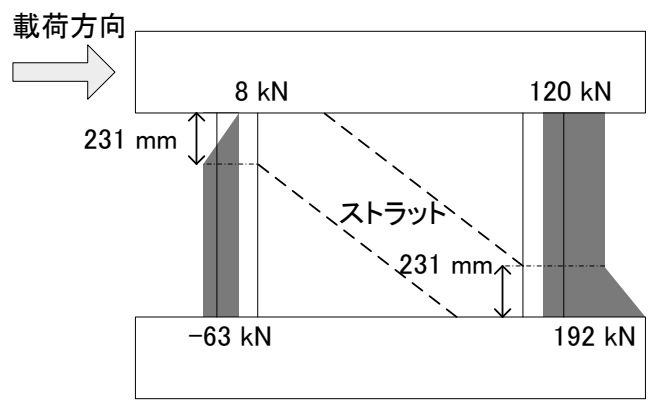

軸力図 ※圧縮が正

図 10 メカニズム時の応力図 
表 4 試験体脚部のせん断力と軸力に関する実験值と解析值の比較

\begin{tabular}{|c|c|c|c|c|}
\hline & \begin{tabular}{|c|} 
引張側柱下 \\
の基礎上
\end{tabular} & $\begin{array}{l}\text { 壁下の } \\
\text { 基礎上 }\end{array}$ & $\begin{array}{l}\text { 圧縮側柱下 } \\
\text { の基礎上 }\end{array}$ \\
\hline \multirow{3}{*}{$\begin{array}{c}\text { せん断力 } \\
(\mathrm{kN})\end{array}$} & $\begin{array}{c}\text { 実験值 } \\
\text { (最大耐力時) }\end{array}$ & 17 & 26 & 186 \\
\hline & $\begin{array}{c}\text { 実験值 } \\
\text { (せん断破壊時) }\end{array}$ & 14 & 14 & 167 \\
\hline & 解析值※2 & 6 & 51 & 165 \\
\hline \multirow{3}{*}{$\begin{array}{c}\text { 軸力 } ※ 1 \\
(\mathrm{kN})\end{array}$} & $\begin{array}{c}\text { 実験值 } \\
\text { (最大耐力時) }\end{array}$ & -91 & 28 & 262 \\
\hline & $\begin{array}{c}\text { 実験值 } \\
\text { (せん断破壊時) }\end{array}$ & -72 & 29 & 243 \\
\hline & 解析值※3 & -63 & 39 & 224 \\
\hline
\end{tabular}

$※ 1:$ 圧縮が正

$※ 2$ : 表左欄より図 11 の $\mathrm{Q}$ (引張側), $\mathrm{Q}$ (壁), $\mathrm{Q}$ (圧縮側) を示す $※ 3$ : 表左欄より図 11 の (引張側), N (壁), N(圧縮側) を示寸

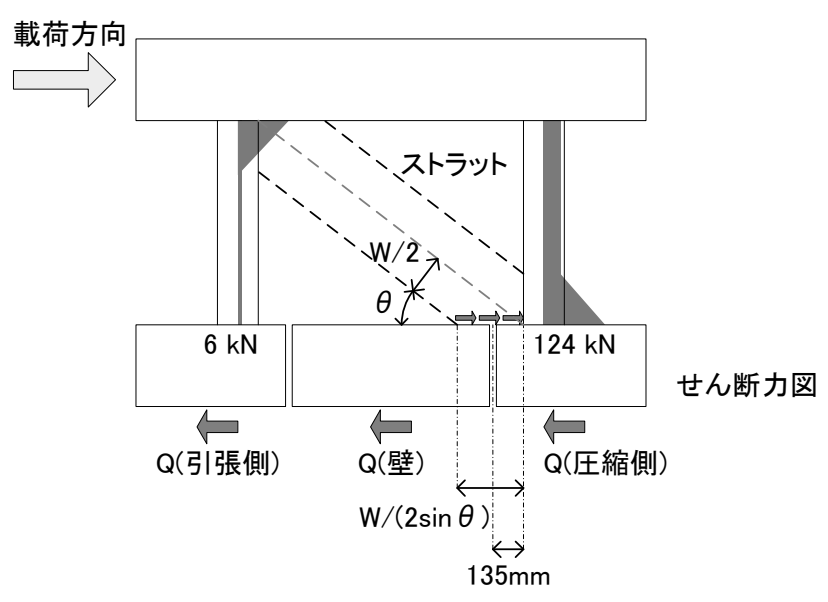

$Q($ 圧縮側 $)=124(\mathrm{kN})+{ }_{b} \mathrm{C}_{h}($ 表3 $) \times 135(\mathrm{~mm})=165 \mathrm{kN}$ $\mathrm{Q}$ (壁) $\quad={ }_{\mathrm{b}} \mathrm{C}_{\mathrm{h}}($ 表3 $) \times(\mathrm{W} /(2 \sin \theta)-135(\mathrm{~mm}))=51 \mathrm{kN}$ $Q($ 引張側 $)=6 \mathrm{kN}$

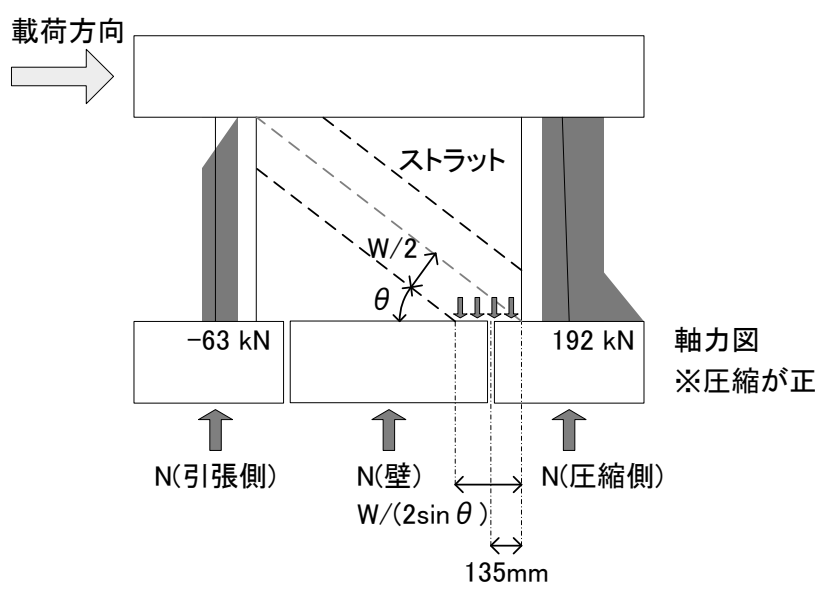

$\mathrm{N}($ 圧縮側 $)=192(\mathrm{kN})+{ }_{\mathrm{b}} \mathrm{C}_{\mathrm{v}}($ 表3 $) \times 135(\mathrm{~mm})=224 \mathrm{kN}$ $\mathrm{N}($ 壁 $) \quad={ }_{\mathrm{b}} \mathrm{c}_{\mathrm{v}}($ 表3 $) \times(\mathrm{W} /(2 \sin \theta)-135(\mathrm{~mm}))=39 \mathrm{kN}$ $\mathrm{N}($ 引張側 $)=-63 \mathrm{kN}$

図 11 試験体各基礎上の応力の解析モデルによる評価過程
の領域は 2.2 節で指摘したストラット幅方向内において応力再配分 が生じる領域と解釈しており, 解析モデルでは幅方向の応力度分布 を平均化して扱ったため (図 1(b)), 一定の数值が評価される. 解析 では壁下の基礎上の応力をやや過大評価する傾向がみられたが，梁 （スタブ）と充填壁の境界の応力伝達については本研究の提案モデ ルで直接的に評価していないため, 今後の検討の余地がある.

以上より, 本研究で提案した解析モデルが層降伏型建物における インフィル架構の柱と充填壁の相互作用, 主に架構の耐力と変形性 能への影響を適切に評価できることを, コンクリートブロック造充 填壁を内蔵した RC 架構の精緻な実験データとの比較を通して検証 した.

\section{4. まとめ}

組積造充填壁を有する $\mathrm{RC}$ 架構の性能評価モデルを提案した．本 モデルは, 層降伏型建物におけるインフィル架構を対象に, 充填壁 を圧縮ストラット置換するためのストラット幅を架構と充填壁間の 力の釣合と変形の適合に基づいて評価するモデルである．本稿の内 容を以下にまとめる.

1) 充填壁を解析モデルに置換するため, 圧縮ストラット幅を評価 する手順を示した. また, 得られたストラット幅に基づいて, 充填壁および周辺柱の荷重一変形関係をバイリニアモデルで 表現する方法を示した。

2) 筆者らが既往の研究で実施したコンクリートブロック充填壁 を有する $\mathrm{RC}$ 架構の基礎上の局所的なせん断力と軸力を計測し た構造実験の概要をまとめた.

3) 本研究で提案した解析モデルにより, 上記試験体の構造性能を 評価した。 その結果, 解析結果は試験体の荷重一変形関係を精 度よく評価でき,また, 試験体の最大耐力時から限界変形時 (柱 のせん断破壊時) にかけての柱と充填壁脚部のせん断力と軸力 負担をおよそ再現できた. 以上より, 本解析モデルにより柱と 充填壁の相互作用を良好に評価できることを検証した。

\section{5. 今後の展望 /課題}

本稿では提案した解析モデルの妥当性を検証するため, インフィ ル架構の柱と充填壁の相互作用が定量的に評価された実験結果の再 現性に焦点を当てて議論を進めた. 本実験は柱と充填壁の力の負担 を評価した特殊な実験であるが，インフィル架構を対象とする一般 の構造実験は既往の研究で数多く実施されている. 筆者らは本解析 モデルの汎用性を確認するため, こうした実験で用いられた本稿の 対象とは構造特性が異なるインフィル架構（とくにレンガ造充填壁 を有する架構)についてもモデルの適合性を継続して検証しており, 稿を改めて報告する計画である.

一方，今後の課題として，本解析モデルを層降伏型建物の耐震性 能評価に適用するに当たり，とくに多スパン架構に対する適合性を 検討する必要がある. また, 解析モデルの適用範囲を明らかにする ため, とくにモデル化の仮定と著しく異なる破壊モード（例えば, 文献 12）で示されるせん断すべり破壊）を呈する架構などへの適合 性を慎重に検討する必要がある. さらに, 将来的に梁が柱に対して 相対的に柔らかい/弱い架構へ適用寸るためには, モデルの修正を 含む引き続きの検討が必要である. 


\section{参考文献}

1) Alidad Hashemi and Khalid M. Mosalam: Seismic Evaluation of Reinforced Concrete Buildings Including Effects of Masonry Infill Walls, PEER Report 2007/100, Pacific Earthquake Engineering Research Center, 2007.7

2) Maidiawati, Yasushi Sanada, Daisuke Konishi and Jafril Tanjung: Seismic Performance of Nonstructural Brick Walls Used in Indonesian R/C Buildings, Journal of Asian Architecture and Building Engineering, Vol. 10, No. 1, pp. 203-210, 2011.5

3) Bryan Stafford Smith: Behavior of Square Infilled Frames, Journal of the Structural Division, Proceedings of the American Society of Civil Engineers, ST 1, pp. 381-403, 1966.2

4) Wood R.H.: Plasticity, composite action and collapse design of unreinforced shear wall panels in frames, Proceedings the Institute of Civil Engineers, Part 2, Vol. 65, pp. 381-411, 1965.6

5) Te-Chang Liauw and Kwok-Hung Kwan: Nonlinear Behaviour of Non-Integral Infilled Frames, Computers \& Structures, Vol. 18, No. 3, pp. 551-560, 1984

6) E. Smyrou, C. Blandon, S. Antoniou, R. Pinho, F. Crisafulli: Implementation and verification of a masonry panel model for nonlinear dynamic analysis of infilled RC frames, Bulletin of Earthquake Engineering, Vol. 9, Issue 5, pp.
1519-1534, 2011.10

7) 日本建築防災協会 : 2001 年改訂版既存鉄筋コンクリート造建築物の而震 診断基準同解説，2001.10

8) 真田靖士, Botirjon Yorkinov : 力の計測に基づくコンクリートブロックを 有する RC 架構の水平力抵抗機構の精査, 日本建築学会構造系論文集, Vol.74, No.641, pp.1335-1344, 2009.7

9) 晉沂雄, 崔琥, 高橋典之, 中埜良昭 : RC 造架構に内蔵された URM 壁の 対角圧縮ストラットに着目した負担せん断力の評価, コンクリート工学 年次論文集，Vol.35，No.2，pp.337-342，2013.7

10) M. J. Nigel Priestley, Ravindra Verma, and Yan Xiao: Seismic Shear Strength of Reinforced Concrete Columns, Journal of Structural Engineering, Vol. 120, No. 8, pp. 2310-2329, 1994.8

11) M. J. N. Priestley and D. M. Elder: Stress-Strain Curves for Unconfined and Confined Concrete Masonry, ACI Journal, Vol. 80, No. 3, pp. 192-201, 1983.5

12) P. G. Asteris, D. J. Kakaletsis, C. Z. Chrysostomou, and E. E. Smyrou: Failure Modes of In-filled Frames, Electronic Journal of Structural Engineering, Vol. 11, pp. 11-20, 2011

（2013年 7 月 7 日原稿受理，2013年 9 月 30 日採用決定） 